\title{
Determinants of Economic Growth in Emerging Countries Under Structural Breaks Consideration
}

\author{
Ebru Tomris AYDOĞAN, Department of Economics, Yeditepe University, Turkey; e-mail: \\ taydogan@yeditepe.edu.tr
}

Çağrı Levent USLU, Department of Economics, Yeditepe University, Turkey; e-mail: cluslu@yeditepe.edu.tr Natalya KETENCI, Department of Economics, Yeditepe University, Turkey; e-mail: nketenci@yeditepe.edu.tr

\section{Yapısal Kırılmalar Işığında Kalkınmakta Olan Ülkelerde Ekonomik Büyümenin Belirleyicileri}

\begin{abstract}
This paper examines the cointegration relationships between economic growth, financial development and trade openness in emerging markets in the presence of structural breaks. The empirical analysis includes 21 emerging countries for 1995-2013, on a quarterly basis. The paper tests for structural changes in the deterministic components of variables in use. Recent econometric techniques are applied in this study to evaluate the presence of structural breaks in the estimated growth equation and to examine the parameters of the model. Existence of the long-run relationships between the series were examined by three alternative cointegration techniques that allow for one, two and unknown number of shifts. The empirical results of the paper indicate a stronger effect of trade openness on economic growth compared to the financial development impact when structural breaks are considered.
\end{abstract}

Keywords $\quad$ : Economic Growth, Financial Development, Trade Openness, Emerging Markets, Structural Breaks.

JEL Classification Codes : $\quad \mathrm{C} 32, \mathrm{~F} 43, \mathrm{O} 47$.

$\ddot{\mathbf{O} z}$

$\mathrm{Bu}$ makale, yapısal kırılmaların mevcudiyetinde gelişmekte olan piyasalardaki ekonomik büyüme, finansal gelişme ve ticaret açıklığı arasındaki eşbütünleşme ilişkilerini incelemektedir. Ampirik analiz, 1995-2013 için, 21 gelişmekte olan ülkeyi üç aylık dönemler bazında kapsar. Makale, kullanılan değişkenlerin belirliyici bileşenlerindeki yapısal değişiklikleri test etmektedir. Bu çalışmada, tahmini büyüme denklemindeki yapısal kırılmaların varlığını değerlendirmek ve modelin parametrelerini incelemek için son ekonometrik teknikler uygulanmıştır. Seriler arasındaki uzun vadeli ilişkilerin varlığı bir, iki ve bilinmeyen harekete izin veren üç alternatif eşbütünleşme tekniği ile incelendi. Makalenin ampirik sonuçları, ticaret açıklığının ekonomik büyüme üzerine etkisinin yapısal kırılmalar dikkate alındığında finansal kalkınmanın etkisine kıyasla daha güçlü olduğunu göstermektedir.

Anahtar Sözcükler : Ekonomik Büyüme, Finansal Büyüme, Ticari Açıklık, Gelişmekte Olan Ekonomiler, Yapısal Kirılmalar. 
Aydoğan, E.T. \& Ç.L. Uslu \& N. Ketenci (2017), "Determinants of Economic Growth in Emerging Countries Under Structural Breaks Consideration", Sosyoekonomi, Vol. 25(33), 37-58.

\section{Introduction}

The debate about the effects of economic growth, financial development, and trade openness has been ongoing in the literature for the last years. The proponents of the endogenous growth theory such as Romer (1986) and Lucas (1988) suggest that financial development may lead to long-run economic growth. Kim et al. (2010) proposes that financial development and trade openness are positively related in the long-run. Trade openness leads to further economic growth through competition, spillover effects, and economies of scale (Kar et al., 2008).

The endogenous growth theory suggests that investments to human capital, research and development, and technological change may influence economic growth positively in the long run. Financial development creates capital flows, technological inventions, and trade (Menyah et al., 2014).

Schumpeter (1934) stated that financial development creates economic growth, which is triggered by technological innovations that stem from the efficient allocation of resources. Lucas (1988) stated that the emphasis that is attributed to finance in economic growth is overvalued. The direction of causality between financial development and economic growth was explained by Patrick (1966) with the demand following and the supply leading hypotheses. The supply-leading hypothesis suggests that there is a unidirectional causality from financial development to economic growth. The demand following hypothesis defines a unidirectional causality from economic growth to financial development. The direction of causality between financial development and economic growth is covered under four categories in the literature. Other than the supply leading and demand following hypotheses which oppose each other in explaining the direction of causality, the third category about the direction of causality refers to the bidirectional causality between financial development and economic growth, and the fourth category (neutral hypothesis) claims that no causality exists between the two.

The finance and economic growth literature consists of four different explanations about the topic: (i) finance increases growth (Schumpeter, 1934), (ii) finance hinders growth (Levine, 2003), (iii) finance pursues growth (Robinson, 1952), and (iv) finance has no influence (Lucas, 1988). Kemal et al. (2004) find that indirect finance is not positively correlated to economic growth.

The studies of Hsueh et al. (2013) for the Asian countries and Agbetsiafia (2004) for Sub-Saharan Africa support the supply-leading hypothesis, and find that the unidirectional causality is from financial development to economic growth. Christopoulos and Tsionas (2004) underline that a unidirectional causality exists from financial development to economic growth in the long-run. Kar et al. (2011) state that trade openness may influence financial development positively and economic growth may be achieved through economic reforms in the long-run. 
The literature consists of many studies (Levine \& Zervos, 1998; Rajan \& Zingales, 1998; Luintel \& Khan, 1999; Wang, 2000; Arestis et al., 2001; Ansari, 2002; Arestis, 2002; Evans et al., 2002; Jalilian \& Kirkpatrick, 2002; Shan \& Morris, 2002; Halıcıoglu (2007), Omoke (2010), Menyah et al. (2014) that employ Granger causality tests in their analyses of the relationship between financial development and economic growth. Goldsmith (1969), Atje and Jovanovic (1993), King and Levine (1993a and 1993b), and Levine and Zervos (1998) applied cross-section analysis to study the relationship between the above mentioned two variables. Roubini and Sala-i-Martin (1991) state that trade and financial liberalization affect economic growth positively.

Shan and Jianhong (2006) find two-way causality between economic growth and financial development by using a Vector Autoregressive Approach (VAR). Time-series studies on financial development and economic growth, which employ causality tests on countries separately in the literature, use different econometric methods varying from standard econometric techniques to multivariate cointegration analysis. Various techniques and methods applied to estimate the direction of causality between economic growth and financial development produce mixed and inconclusive results.

Robinson (1952) stated that financial development is the outcome of economic growth. Patrick (1966) explained the relationship between financial development and economic growth by emphasizing two perspectives: the demand-following hypothesis, and the supply-leading hypothesis, which analyze the direction of causality.

Halıcıoğlu (2007) employs the bounds testing approach for cointegration and Granger causality analysis to indicate that a uni-directional causation is achieved from financial development to economic growth for the 1968-2005 period in Turkey. Yücel (2009) utilizes Augmented Dickey-Fuller (ADF), Granger causality, and Johansen and Juselius (JJ) tests and states bi-directional causality from both trade openness and financial development to economic growth and vice versa for the 1989M1-2011M11 period for Turkey.

The Granger causality test empirical results for Nigeria between the 1970 and 2005 period reflect growth led trade. Chimobi (2010) indicates that economic growth necessitates credits and also the supply of money which enhances trade openness. Ang (2007) suggests that the causal relationship between finance and growth may be bi-directional for countries with financial repression that has a positive effect on financial development. Uddin et al. (2013) employs Autoregressive Distributive Lag (ARDL) bounds testing and Gregory Hansen's (1996) structural break cointegration approach for the period between 1971-2011 for Kenya and states that economic growth is positively affected by the development of the financial sector in the long-run. Liang and Teng (2006) emphasize that VAR analysis results for China over the period 1952-2011 reflects a uni-directional causality from economic growth to financial development.

Federici and Caprioli (2009) apply a time-series approach by using the VAR model and emphasize that financially more developed countries are the ones to avoid currency 
crises. Yang and Yi (2008) allocate annual data for Korea for the period between 1971 and 2002 by utilizing the superexogeneity methodology, and indicate that finance causes growth. Demetriades and Hussein (1996) find very little support for finance to cause economic development. Rather, authors claim that the results for most of the countries of the study reflect a bi-directional relationship between financial development and economic growth, denoting that financial reforms may cause further economic development. Al-Malkawi et al. (2012) show the negative relationship between financial development and economic growth by using time-series data from 1974 to 2008 and employing the ARDL approach to cointegration. The results for the UAE that reflect a bi-directional causality between the two variables are not in line with Patrick's (1966) two hypotheses.

This study investigates relations between economic growth, financial development and trade openness in emerging markets in the presence of structural breaks. The quarterly data for 21 emerging countries are used in this research and cover the period from 1995 to 2013. Emerging countries are easily exposed to external and internal shocks due to their transition studies of developments. Evolving infrastructure makes emerging countries vulnerable to any fluctuations of the global economic system. Therefore, consideration of structural breaks in estimation of economic growth determinants for emerging countries carries high importance for accurate results. We planned to estimate the wider list of emerging countries, however availability of consistent data for the longest period limited this research to 21 emerging countries. The novelty of this study is the consideration of structural breaks in the investigation of economic growth models. To our knowledge there are no similar studies in the literature. The rest of the paper is organized as follows. In the next section, the applied methodological approach is presented. In section 3, the obtained empirical results are reported, and finally, the last section concludes.

\section{Methodology}

Empirical studies on relationships between economic growth and its determinants in emerging countries estimate the basic model that demonstrates the linear relationships between variables, for example see Halicioglu (2007), Yucel (2009), Omoke (2010). Following these studies, we examine relationships between economic growth, financial development and trade openness in emerging countries, which take the following form:

$$
\ln G R_{\mathrm{j}, \mathrm{t}}=\beta_{0}+\beta_{1} \ln F D_{j . t}+\beta_{2} \ln T O_{j, t}+\varepsilon_{t}
$$

where $G R_{j, t}$ is economic growth of the $j$ th country at period $t$. Following general practice in the literature economic growth is presented by the real income per capita. $F D_{j, t}$ is the financial development of the $j$ th country and is proxied by Money Supply (M2) as a ratio to GDP of the particular country. Finally, $T O_{j, t}$ is the trade openness of the $j$ th country and expressed as sum of export and import as share to the GDP at period $t . \varepsilon_{t}$ is the error term associated with each observation at period $t$. Financial development and increase in the degree of trade openness are expected to have a positive effect on economic growth of a country, therefore, coefficients $\beta_{1}$ and $\beta_{2}$ are expected to have positive signs. 


\subsection{Structural Change Presence}

When studying relationships between economic growth, financial development and trade openness, it is important to take into account structural breaks that series may exhibit in the long run due to the vulnerability of these series to internal or external shocks. Estimation of the regression model (1) in the frame of structural breaks presence is conducted by employing the Kejriwal and Perron $(2008,2010)$ approach. The Kejriwal and Perron $(2008,2010)$ approach tests regression models for unknown multiple structural breaks and provides the regression estimation results that allow the presence of structural breaks. One of significant advantages of this approach is that both stationary and nonstationary variables are allowed in the regression model, which is the extension of the Bai and Perron's (1998) framework, where only stationary variables are allowed. Another advantage is related to heteroskedasticity and serial correlation that are allowed in the model.

The multiple linear regression is expressed in the following form where $m$ breaks are allowed, which is associated with $m+1$ regimes.

$$
y_{t}=x_{t}^{\prime} \beta+z_{t}^{\prime} \delta_{j}+e_{t}
$$

where $t$ is the time period that may be represented by following partitions $T_{j-1}+1, \ldots, T_{j}$ with $j=1, \ldots, m+1$ regimes. $y_{t}, x_{t}$ and $z_{t}$ are the dependent variable and vectors of covariates. Size of $x_{t}$ vector is ( $\left.p x l\right)$ with $p$ independent variables and $\beta$ coefficients that do not change across regimes. Size of $z_{t}$ is $(q x l)$ where $q$ is the number of changeable across regimes independent variables related to the vector of coefficients $\delta_{j}$. Finally, $e_{t}$ is error term of the regression ${ }^{1}$.

\subsection{Unit Root Tests}

The presence of the unit root in estimated variables is tested by two alternative tests. Firstly we employed the $\mathrm{Ng}$ and Perron (2001) unit root test with the maximum power against $I(0)$ alternatives. This test is based on the generalized least squares detrending procedure, which is initially proposed by Elliot, Rothenberg and Stock (1996). Ng and Perron suggested to use a minimized value of the modified Akaike information criterion (AIC) for the lag length selection to reach good size and power properties of the unit root test.

Secondly we employed the Carrion-i-Silvestre et al. (2009) unit root test that allows for multiple structural shifts, maximum five shifts. This test initially was proposed by Kim and Perron (2009) and is superior to alternative tests because it allows multiple unknown shifts under both the null and alternative hypothesis of unit root and stationarity, respectively. Alternative unit root tests allow structural breaks only under the alternative 
Aydoğan, E.T. \& Ç.L. Uslu \& N. Ketenci (2017), "Determinants of Economic Growth in Emerging Countries Under Structural Breaks Consideration”, Sosyoekonomi, Vol. 25(33), 37-58.

hypothesis of stationarity, Zivot and Andrews (1992), Perron and Vogelsang (1992), Perron (1997), Vogelsang and Perron (1998).

Alternative unit root tests have to be applied according to properties of time series, therefore firstly the presence of structural shifts has to be investigated. Ignorance of structural breaks in the case when they exist can lead to misspecification errors. Therefore, the Perron and Yabu (2009) test is employed to examine univariate time series for stability properties. The test is applied to series when their integration order is a priori unknown. Exp$W_{F S}$ is the statistics, which is used in the Perron and Yabu (2009) test and is based on a quasiFeasible Generalized Least Squares (FGLS) technique. The null hypothesis of the test is no structural change in the deterministic components. Three different models are proposed by the test, which test for a structural change in the level, in the slope of the trend and in both the level and slope of the time trend. We apply the third model in this study to examine the regression for the presence of structural breaks in both the level and the slope of the time trend.

\subsection{Cointegration}

To countries, which demonstrate one structural shift in the regression, the Gregory and Hansen (1996) test was employed, which allows for one break in the level (model C), in the level with trend (model C/T), and in the level and slope coefficients (model C/S). The Hatemi-J (2008) cointegration test was applied to countries, where two structural shifts were detected by the Bai and Perron (1998) test. The Hatemi-J (2008) test similar to the Gregory and Hansen (1996) test offers three various models: model C, model C/T and model C/S.

In countries, where more than two breaks were found, the Maki (2012) cointegration test was applied. Bai and Perron (1998) approach for structural shifts detection and the Kapetanios (2005) unit root test are in the origin of the Maki (2012) cointegration test that allows for unknown structural shifts. The Maki (2012) procedure tests a regression for the null hypothesis of no cointegration versus the alternative hypothesis of cointegration with unknown number of shifts $i$ that is less or equal to the maximum number of shifts $(i \leq k)$. The significant advantage of the Maki (2012) test that it allows for more than two breaks in a regression.

\section{Empirical Results}

\subsection{Unit Root Tests}

The results of the Perron and Yabu (2009) test are presented in Table 1. The null hypothesis of no structural break is not rejected in GDP per capita variables for Chili, Malaysia, Peru, Thailand and Turkey at five percent significance level, and is rejected at ten percent significance level in case of Colombia. For Financial Development series the null hypothesis was not rejected in cases of Estonia and Malaysia. For Trade Openness series the null was not rejected in case of Estonia at five percent significance level and the null was rejected at ten percent significance level in case of Peru. In all other cases the null hypothesis of no break was rejected. The Therefore, $\mathrm{Ng}$ and Perron (2001) unit root test is applied to 
countries where the null hypothesis of no structural shifts was not rejected by the Perron and Yabu (2009) test and the Carrion-i-Silvestre et al. (2009) unit root test is applied to series where structural shifts were detected. Countries where the null was rejected at ten percent significance level are estimated by both unit root tests.

Table: 1

\section{Perron - Yabu (2009) Test for Structural Changes in Series}

\begin{tabular}{|c|c|c|c|c|c|c|}
\hline Country & EXP-WFs test & $\hat{T}_{1}$ & EXP-W $W_{F S}$ test & $\hat{T}_{1}$ & EXP-WFs test & $\hat{T}_{1}$ \\
\hline & GDP/capita & & $M 2$ & & Openness & \\
\hline Argentina & $8.47 * *$ & 27 & $11.93^{* * *}$ & 19 & $6.94 * *$ & 37 \\
\hline Brazil & $6.17 * *$ & 37 & $4.72 * *$ & 52 & $21.21^{* * *}$ & 37 \\
\hline Bulgaria & $11.54 * *$ & 14 & $111.4^{* * *}$ & 13 & $19.19^{* * *}$ & 36 \\
\hline Chile & 1.75 & - & $8.37 * *$ & 16 & $5.87 * *$ & 36 \\
\hline Colombia & 3.31 & 26 & $13.13^{* * *}$ & 20 & $41.40 * *$ & 37 \\
\hline Estonia & $25.15^{* * *}$ & 56 & 1.99 & - & 1.44 & - \\
\hline Hungary & $64.87 * *$ & 52 & $10.73 * *$ & 56 & $12.75^{* * *}$ & 55 \\
\hline India & $8.63^{* * *}$ & 42 & $5.78^{* * *}$ & 38 & $25.26^{* * *}$ & 36 \\
\hline Indonesia & $32.23 * *$ & 13 & 32.07 ** & 13 & $27.53^{* *}$ & 38 \\
\hline Lithuania & $16.97 * *$ & 56 & $13.32^{* * *}$ & 44 & $8.23 * *$ & 45 \\
\hline Malaysia & 2.29 & - & 2.22 & - & $24.95^{* * *}$ & 37 \\
\hline Mexico & $5.20^{* * *}$ & 24 & $12.02 * *$ & 20 & $5.76 * *$ & 55 \\
\hline Peru & 1.27 & - & $12.09^{* * *}$ & 29 & 2.81 & 38 \\
\hline Philippines & $4.83^{* * *}$ & 34 & $15.54 * *$ & 17 & $8.03 * *$ & 24 \\
\hline Poland & $6.17 * *$ & 24 & $9.45 * *$ & 27 & $24.57^{* *}$ & 36 \\
\hline Romania & 10.77 ** & 57 & $18.74 * *$ & 16 & $4.51^{*}$ & 32 \\
\hline Russia & $6.99 * *$ & 45 & $6.22 * *$ & 55 & $9.35 * *$ & 37 \\
\hline South Africa & $6.08^{* * *}$ & 41 & $9.84 * *$ & 50 & $7.91 * *$ & 34 \\
\hline Thailand & 0.93 & - & $7.59 * *$ & 18 & $7.68 * *$ & 17 \\
\hline Turkey & 1.77 & - & $111.4^{* * *}$ & 26 & $24.91^{* * *}$ & 35 \\
\hline Ukraine & $24.13^{* *}$ & 40 & $6.77 * *$ & 52 & $7.93 * *$ & 31 \\
\hline
\end{tabular}

Notes: * and ** denote the rejection of the null hypothesis at the 5\% and $1 \%$ significance levels. Trimmer parameter $\varepsilon=0.15$ is used. The critical values are taken from Perron and Yabu (2009), Table $2 c$ and are 2.48, 3.12 and 4.47 for the $10 \%, 5 \%$ and $1 \%$ significance levels respectively.

Results of the Ng and Perron (2001) unit root test are presented in Table 2. The test is applied to series that did not demonstrate structural shifts in the Perron and Yabu (2009) test. The results of four alternative statistics of the test are consistent with each other. The unit root hypothesis was supported in levels of all series. The null hypothesis of the unit root was rejected for GDP per capita series in their differences in cases of Colombia, Malaysia and Thailand; for Financial Development series in case of Malaysia and for Trade Openness series in case of Estonia. The results of the unit root test provide enough evidence to conclude the non-stationarity of the series. 
Table: 2

The Ng and Perron (2001) Unit Root Test

\begin{tabular}{|c|c|c|c|c|c|c|c|c|}
\hline \multirow[t]{2}{*}{ Country } & \multicolumn{2}{|c|}{$\mathrm{MZ}_{\alpha}^{\mathrm{GLS}}$} & \multicolumn{2}{|c|}{$\mathrm{MZ}_{\mathrm{t}}^{\mathrm{GLS}}$} & \multicolumn{2}{|c|}{$\mathrm{MSB}^{\mathrm{GLS}}$} & \multicolumn{2}{|c|}{$\mathrm{MP}_{\mathrm{T}}{ }_{\mathrm{T}}^{\mathrm{GLS}}$} \\
\hline & Level & $\Delta$ & Level & $\Delta$ & Level & $\Delta$ & Level & $\Delta$ \\
\hline & \multicolumn{8}{|c|}{ GDP/capita } \\
\hline Chile & 1.36 & -0.91 & 1.08 & -0.63 & 0.79 & 0.68 & 49.58 & 24.07 \\
\hline Colombia & 1.37 & $-18.32 * *$ & 0.89 & $-2.99 * *$ & 0.65 & $016^{* *}$ & 35.66 & $1.46^{*}$ \\
\hline Malaysia & 1.35 & $-10.19 *$ & 1.09 & $-2.23^{*}$ & 0.81 & $0.22 *$ & 50.75 & $2.48 *$ \\
\hline Peru & 0.47 & -0.18 & 0.25 & -0.30 & 0.53 & 1.65 & 22.67 & 134.25 \\
\hline Thailand & 1.07 & $-35.97 * *$ & 0.77 & $-4.23 * *$ & 0.72 & $0.12^{* * *}$ & 39.96 & $0.71 * *$ \\
\hline \multirow[t]{2}{*}{ Turkey } & 1.13 & -0.19 & 0.99 & -0.25 & 0.88 & 1.29 & 57.14 & 85.08 \\
\hline & \multicolumn{8}{|c|}{$M 2$} \\
\hline Estonia & 0.88 & -3.51 & 0.81 & -1.32 & 0.91 & 0.38 & 57.94 & 6.98 \\
\hline \multirow[t]{2}{*}{ Malaysia } & 1.82 & $-34.68 * *$ & 3.77 & $-4.16^{* *}$ & 2.07 & $0.12^{* * *}$ & 325.62 & $0.71 * *$ \\
\hline & \multicolumn{8}{|c|}{ Openness } \\
\hline Estonia & 1.05 & $-34.87 * *$ & 0.88 & $-4.18 * *$ & 0.84 & $0.12 * *$ & 51.76 & 0.70 \\
\hline Peru & -0.49 & -3.96 & -0.25 & -1.39 & 0.51 & 0.35 & 17.67 & 6.19 \\
\hline
\end{tabular}

Notes: $M Z_{\alpha}^{G L S}$ is the modified Phillip-Perron test $M Z_{\alpha} ; M Z_{t}^{G L S}$ is the modified Phillip-Perron $M Z_{t}$ test; $M S B^{G L S}$ is the modified Sargan-Bhargava test; $M P_{T}^{G L S}$ is the modified point optimal test, for details see Ng and Perron (2001). The lag order is chosen by using the modified AIC (MAIC) suggested by Ng and Perron (2001). ** denotes the rejection of the null hypothesis at the 1\% significance level. The critical values are reported in $\mathrm{Ng}$ and Perron (2001).

The Carrion-i-Silvestre et al. (2009) unit root test is applied to series with structural shifts. The results of the test estimations are presented in Table 3. Statistics of the test are presented in Table 3, where possible break locations $\widehat{T}_{l}$ are displayed in the last three columns. The structural break is allowed in both the level and the slope of the time trend. Estimated first break locations are different however, it is possible to see common break dates in the estimated countries. First break dates in general are concentrated around the years 1997-1999 which can be characterized by the Asian crisis of 1997 that affected most of the emerging markets. Second break dates are diverse, where some of the countries had an effect of Asian crisis and some of countries had an effect of the global financial crisis in their second break dates. Finally, third break dates are generally concentrated around the years 2008-2010 demonstrating the effect of the global financial crisis on economies of emerging countries.

The unit root hypothesis was rejected for GDP per capita series in cases of Bulgaria, Estonia, Hungary, Lithuania and Poland and the US. Financial Development series displayed the non-stationarity in all countries except Hungary and Peru. The hypothesis of nonstationarity in Openness series was rejected only in the Turkey case. Results of the unit root test demonstrate the presence of mixed integration order of series in the presence of structural shifts. Next, structural shifts presence and cointegration tests for the economic growth equation (1) were conducted. 
Aydoğan, E.T. \& Ç.L. Uslu \& N. Ketenci (2017), "Determinants of Economic Growth in

Emerging Countries Under Structural Breaks Consideration”, Sosyoekonomi, Vol. 25(33), 37-58.

Table: 3

The Carrion-i-Silvestre et al. (2009) Unit Root Test

\begin{tabular}{|c|c|c|c|c|c|c|c|}
\hline Country & $\mathrm{MZ}_{\alpha}^{\mathrm{GLS}}$ & $\mathrm{MZ}_{\mathrm{t}}^{\mathrm{GLS}}$ & $\mathrm{MSB}^{\mathrm{GLS}}$ & $\mathrm{MP}_{\mathrm{T}}^{\mathrm{GLS}}$ & $\hat{T}_{1}$ & $\hat{T}_{2}$ & $\hat{T}_{3}$ \\
\hline & \multicolumn{7}{|c|}{ GDP/capita } \\
\hline Argentina & -33.01 & -4.05 & 0.12 & 8.43 & 1998Q1 & 2002Q1 & 2008Q2 \\
\hline Brazil & -30.76 & -3.91 & 0.12 & 7.24 & 1996Q3 & 1999Q1 & 2010Q4 \\
\hline Bulgaria & $-36.25^{*}$ & $-4.25 *$ & $0.11^{*}$ & $6.87 *$ & 1996Q4 & 1998Q3 & 2008Q3 \\
\hline Estonia & $-35.79^{*}$ & $-4.22 *$ & $0.11^{*}$ & $7.69 *$ & 2002Q1 & 2007Q4 & 2010Q1 \\
\hline Hungary & $-36.29 *$ & $-4.25 *$ & $0.11 *$ & $6.13 *$ & 2004Q4 & 2006Q4 & 2008Q4 \\
\hline India & -35.05 & -4.17 & 0.11 & 8.13 & 1996Q4 & 2003Q4 & 2005Q4 \\
\hline Indonesia & -32.96 & -4.05 & 0.12 & 7.68 & 1997Q3 & 1999Q2 & 2002Q3 \\
\hline Lithuania & $-35.89^{*}$ & $-4.23 *$ & $0.11 *$ & $6.96 *$ & 1996Q3 & 1998Q3 & 2008Q4 \\
\hline Mexico & -14.17 & -2.65 & 0.18 & 19.97 & 2000Q3 & 2005Q3 & 2008Q3 \\
\hline Philippines & -30.09 & -3.86 & 0.12 & 8.70 & 2000Q4 & 2007Q4 & 2009Q4 \\
\hline Poland & $-36.46^{*}$ & $-4.25 *$ & $0.11 *$ & $6.71 *$ & 1996Q4 & 1998Q4 & 2006Q4 \\
\hline Romania & -32.07 & -3.99 & 0.12 & 8.37 & 1996Q4 & 1998Q4 & 2006Q4 \\
\hline Russia & -18.62 & -3.05 & 0.16 & 16.18 & 1997Q4 & 1999Q3 & 2008Q3 \\
\hline South Africa & -10.46 & -2.28 & 0.22 & 28.61 & 1997Q4 & 2003Q4 & 2008Q3 \\
\hline \multirow[t]{2}{*}{ Ukraine } & -16.57 & -2.87 & 0.17 & 16.32 & 2001Q2 & 2003Q1 & 2008Q4 \\
\hline & \multicolumn{7}{|c|}{$M 2$} \\
\hline Argentina & -29.92 & -3.79 & 0.12 & 8.86 & 1999Q3 & 2001Q2 & 2004Q1 \\
\hline Brazil & -28.28 & -3.75 & 0.13 & 9.07 & 1999Q2 & 2007Q3 & 2010Q4 \\
\hline Bulgaria & -32.45 & -4.02 & 0.12 & 8.84 & 1996Q3 & 1998Q2 & 2009Q1 \\
\hline Chile & -11.12 & -2.35 & 0.21 & 26.23 & 1997Q1 & 2004Q2 & 2006Q2 \\
\hline Colombia & -32.34 & -4.01 & 0.12 & 8.37 & 1999Q4 & 2001Q3 & 2008Q3 \\
\hline Hungary & $-34.13^{*}$ & $-4.13 *$ & 0.12 & $7.62 *$ & 2002Q4 & 2004Q4 & 2009Q1 \\
\hline India & -33.30 & $-4.08 *$ & 0.12 & $8.13 *$ & 1996Q3 & 1999Q1 & 2000Q4 \\
\hline Indonesia & -14.76 & -2.70 & 0.18 & 15.08 & 1996Q3 & 1998Q2 & 2000Q1 \\
\hline Lithuania & -31.51 & -3.96 & 0.12 & 9.39 & 1997Q3 & 2002Q1 & 2008Q4 \\
\hline Mexico & -23.84 & -3.44 & 0.14 & 11.38 & 1999Q3 & 2001Q2 & 2008Q3 \\
\hline Peru & $-36.33^{*}$ & $-4.24 *$ & $0.11 *$ & $7.81 *$ & 1997Q1 & 1999Q1 & 2004Q2 \\
\hline Philippines & -22.24 & -3.31 & 0.14 & 12.08 & 1999Q1 & 2006Q1 & 2010Q2 \\
\hline Poland & -28.02 & -3.78 & 0.13 & 8.33 & 1996Q4 & 1998Q4 & 2002Q4 \\
\hline Romania & -34.31 & $-4.13 *$ & 0.12 & $7.87 *$ & 1996Q4 & 1998Q4 & 2003Q4 \\
\hline Russia & -13.64 & -2.60 & 0.19 & 18.00 & 1998Q2 & 2007Q3 & 2009Q3 \\
\hline South Africa & -21.05 & -3.23 & 0.15 & 13.19 & 1999Q4 & 2002Q1 & 2009Q1 \\
\hline Thailand & -19.53 & -3.13 & 0.16 & 12.14 & 1998Q3 & 2008Q1 & 2011Q1 \\
\hline Turkey & -22.80 & -3.37 & 0.15 & 11.65 & 1997Q1 & 1999Q1 & 2008Q4 \\
\hline \multirow[t]{2}{*}{ Ukraine } & -16.40 & -2.86 & 0.17 & 15.95 & 2001Q1 & 2003Q1 & 2009Q4 \\
\hline & \multicolumn{7}{|c|}{ Openness } \\
\hline Argentina & -26.43 & -3.63 & 0.14 & 9.48 & 2001Q3 & 2008Q2 & 2010Q1 \\
\hline Brazil & -27.89 & -3.72 & 0.13 & 8.70 & 2002Q2 & 2008Q3 & 2011Q1 \\
\hline Bulgaria & -27.60 & -3.71 & 0.13 & 10.32 & 2001Q1 & 2002Q4 & 2008Q2 \\
\hline Chile & -21.35 & -3.24 & 0.15 & 11.83 & 2002Q4 & 2007Q2 & 2009Q2 \\
\hline Colombia & -27.12 & -3.65 & 0.14 & 8.57 & 2004Q1 & 2008Q3 & 2010Q2 \\
\hline Hungary & -28.43 & -3.76 & 0.13 & 8.73 & 2001Q1 & 2008Q2 & 2010Q2 \\
\hline India & -28.38 & -3.72 & 0.13 & 10.01 & 1996Q4 & 1998Q4 & 2003Q4 \\
\hline Indonesia & -15.27 & -2.66 & 0.17 & 18.18 & 2000Q3 & 2003Q3 & 2008Q4 \\
\hline Lithuania & -24.37 & -3.48 & 0.14 & 11.46 & 1998Q1 & 2004Q3 & 2006Q2 \\
\hline Malaysia & -13.11 & -2.49 & 0.19 & 20.89 & 1997Q1 & 1998Q4 & 2008Q4 \\
\hline Mexico & -24.93 & -3.52 & 0.14 & 9.85 & 1996Q4 & 1998Q3 & 2008Q3 \\
\hline Philippines & -30.02 & -3.87 & 0.13 & 8.27 & 2000Q4 & 2008Q3 & 2010Q4 \\
\hline Poland & -20.93 & -3.23 & 0.15 & 11.82 & 2000Q4 & 2008Q3 & 2011Q2 \\
\hline Romania & -31.91 & -3.98 & 0.13 & 8.40 & 1997Q4 & 1999Q4 & 2005Q4 \\
\hline Russia & -30.97 & -3.93 & 0.13 & 9.39 & 1997Q4 & 2002Q1 & 2008Q3 \\
\hline South Africa & -27.36 & -3.69 & 0.14 & 8.96 & 2002Q1 & 2008Q3 & 2010Q2 \\
\hline Thailand & -22.46 & -3.31 & 0.15 & 12.28 & 1999Q1 & 2003Q2 & 2008Q3 \\
\hline Turkey & $-35.09^{*}$ & $-4.19 *$ & 0.12 & $7.77 *$ & 1998Q1 & 2000Q2 & 2008Q3 \\
\hline Ukraine & -21.52 & -3.26 & 0.15 & 11.81 & 1999Q3 & 2008Q3 & 2010Q2 \\
\hline
\end{tabular}

Notes: * denotes the rejection of the null hypothesis at the 5\% significance level. The critical values were obtained by simulations using 1,000 steps to approximate the Wiener process and 10,000 replications. The test is run for model 3, where the structural break affects both the level and the slope of the time trend. The null hypothesis is rejected in favor of stationarity when the estimated value is smaller than the critical value for MSB and MPT tests. 


\subsection{Structural Change Presence}

The Kejriwal and Perron $(2008,2010)$ methodology is applied in order to test the regression for structural change presence. This methodology allows for presence of stationary as well as non-stationary variables in the regression, in contrast to Bai and Perron (1998) procedure that is developed for only stationary variables. The Kejriwal and Perron $(2008,2010)$ test is designed for cointegrated regression models, therefore firstly the cointegration relationships of the model have to be examined. Table 4 presents the results of two statistics, Trace and Max-Eigenvalue of the Johansen cointegration test estimations ${ }^{2}$. The lag length is presented in the second column of the table. The choice of the lag length is based on the Akaike Information Criterion (AIC). Results of the Johansen cointegration test are presented for $r$ with maximum value of 2. Results of the test statistics are consistent with each other in most cases. In all cases, at least one test statistics detected minimum one cointegration relationship in economic growth equation (1). The results of the Johansen cointegration test estimations indicate on existence of cointegration relationships among estimated variables when structural breaks are not considered.

Table: 4

The Johansen Cointegration Test

\begin{tabular}{|c|c|c|c|c|c|c|c|}
\hline \multirow{2}{*}{$\begin{array}{l}\text { Country } \\
\text { Gdp/capita }\end{array}$} & \multirow[t]{2}{*}{ Lag } & \multicolumn{2}{|c|}{ Trace statistics } & \multirow[b]{2}{*}{$\mathrm{r} \leq 2$} & \multicolumn{2}{|c|}{ Max-Eigen Statistics } & \multirow[b]{2}{*}{$\mathrm{r} \leq 2$} \\
\hline & & $\mathrm{r}=0$ & $\mathrm{r} \leq 1$ & & $\mathrm{r}=0$ & $\mathrm{r} \leq 1$ & \\
\hline Argentina & 9 & $30.43 *$ & 13.58 & 2.11 & 16.85 & 11.47 & 2.11 \\
\hline Brazil & 6 & $31.52 *$ & 6.14 & 0.16 & $25.38 *$ & 5.98 & 0.16 \\
\hline Bulgaria & 9 & $48.79^{*}$ & $22.03 *$ & 3.72 & $26.77 *$ & $18.31 *$ & 3.72 \\
\hline Chile & 9 & $81.37 *$ & $31.76^{*}$ & 0.09 & $49.60 *$ & $31.67 *$ & 0.09 \\
\hline Colombia & 5 & $34.08 *$ & 12.93 & 0.14 & $21.15^{*}$ & 12.79 & 0.14 \\
\hline Estonia & 6 & 34.24 & 9.05 & 1.65 & $25.18 *$ & 7.40 & 1.65 \\
\hline Hungary & 6 & $40.77 *$ & 15.24 & $4.23 *$ & $25.53 *$ & 11.02 & $4.22 *$ \\
\hline India & 7 & $36.69^{*}$ & 14.98 & 1.28 & $21.71^{*}$ & 13.70 & 1.28 \\
\hline Indonesia & 7 & $52.79 *$ & $19.22 *$ & 2.98 & $33.57 *$ & $16.24 *$ & 2.98 \\
\hline Lithuania & 7 & $36.82 *$ & 16.73 & 4.94 & 20.09 & 11.79 & $4.93 *$ \\
\hline Malaysia & 5 & $46.41^{*}$ & $15.49 *$ & 0.18 & 30.55 & $15.68^{*}$ & 0.18 \\
\hline Mexico & 2 & $47.28^{*}$ & $22.85^{*}$ & 8.38 & $24.42 *$ & $14.47 *$ & $8.37 *$ \\
\hline Peru & 5 & $41.09^{*}$ & $16.09^{*}$ & 0.00 & $25.00 *$ & $16.09^{*}$ & 0.00 \\
\hline Philippines & 6 & $30.71 *$ & 11.66 & 0.55 & 19.05 & 11.11 & 0.54 \\
\hline Poland & 6 & $35.33^{* *}$ & 13.15 & $4.12 *$ & $22.18^{*}$ & 9.02 & $4.12^{*}$ \\
\hline Romania & 6 & $43.49^{*}$ & 15.10 & $6.08 *$ & $28.39 *$ & 9.02 & $6.08 *$ \\
\hline Russia & 5 & $30.26^{*}$ & $12.41^{*}$ & $5.30 *$ & $17.85 *$ & 7.10 & $5.30 *$ \\
\hline South Africa & 9 & $44.96 *$ & $18.93^{*}$ & $5.55 *$ & $26.02 *$ & $13.38 *$ & $5.55^{*}$ \\
\hline Thailand & 6 & $32.69^{*}$ & 15.31 & 3.22 & 17.38 & 12.09 & 3.22 \\
\hline Turkey & 5 & $38.62 *$ & $15.90 *$ & 3.34 & $22.72 *$ & 12.56 & 3.34 \\
\hline Ukraine & 1 & $32.36^{*}$ & $16.56^{*}$ & $3.93 *$ & $15.80 *$ & 12.63 & $3.93 *$ \\
\hline
\end{tabular}

Notes: * denotes statistical significance at $5 \%$ level.

The results of the Kejriwal and Perron $(2008,2010)$ test are presented in Table 5. The test investigates for the structural shifts presence in the economic growth equation of countries. The Sup $\mathrm{F}(l)$ statistics were found significant for at least one value of $l$ in all

2 Estimations of the Johansen cointegration test are based on the assumption of non-stationarity of series. The non-stationarity of series was supported by the Ng and Perron (2001) test results, which was applied to all variables. Results of the Ng and Perron (2001) unit root test for all variables are available from the author upon request. 
countries except Brazil, Lithuania and Poland. UDmax and WDmax tests are presented in last two columns of the table and have the null hypothesis of no structural shifts presence. The null is rejected by both tests, except Brazil, Lithuania and Poland. The strong evidence of structural changes in all regressions, except three countries, is provided by tests.

Table: 5

Structural Break Tests of Kejriwal and Perron (2008, 2010)

\begin{tabular}{|c|c|c|c|c|c|c|c|}
\hline Country & Sup (1) & Sup F(2) & Sup F(3) & Sup F(4) & Sup F(5) & UDmax & WDmax \\
\hline Argentina & 1.61 & $213.68 * *$ & $18.18^{* *}$ & $135.72 * *$ & $63.79 * *$ & $213.68 * *$ & $253.93 * *$ \\
\hline Brazil & 0.01 & 0.90 & 1.81 & 2.15 & 3.35 & 3.35 & 7.37 \\
\hline Bulgaria & 0.41 & $9.16 * *$ & $9.12 * *$ & 2.14 & 1.62 & 9.16 & $12.32 * *$ \\
\hline Chile & 0.02 & $29.94 * *$ & $12.37 * *$ & $9.69 * *$ & $16873.04 * *$ & $16873.04 * *$ & $34232.32 * *$ \\
\hline Colombia & 0.15 & $17.27 * *$ & $17.74 * *$ & $114.71^{* * *}$ & $32.48 * *$ & $114.71 * *$ & $197.23 * *$ \\
\hline Estonia & 0.02 & $3269.86 * *$ & $10317.95 * *$ & $239.22^{* * *}$ & $1540.25 * *$ & $10317.95 * *$ & $14853.71^{* * *}$ \\
\hline Hungary & 0.02 & $23.82 * *$ & $105.56^{* *}$ & $1327.53^{* * *}$ & $9526.19 * *$ & $9526.19 * *$ & $20904.03 * *$ \\
\hline India & 0.21 & 1.40 & $24.16^{* *}$ & $334.05^{* * *}$ & $332.64 * *$ & $334.05 * *$ & $729.94 * *$ \\
\hline Indonesia & 3.74 & $44.77 * *$ & $100.68 * *$ & $45.83^{* * *}$ & $1158.79 * *$ & $1158.79 * *$ & $2542.83 * *$ \\
\hline Lithuania & 0.001 & 0.08 & 0.18 & 0.24 & 0.18 & 0.24 & 0.41 \\
\hline Malaysia & 0.002 & 6.84 & $11.57 * *$ & 4.19 & 9.43 & $11.57 * *$ & $20.70 * *$ \\
\hline Mexico & 11.03* & $15.57 * *$ & $76.47 * *$ & $122.38 * *$ & $2202.03 * *$ & $2202.03 * *$ & $4832.08 * *$ \\
\hline Peru & 0.01 & $75.01 * *$ & $20.61 * *$ & $8.68 * *$ & $14.25 * *$ & $75.01^{* *}$ & $84.09 * *$ \\
\hline Philippines & 0.00 & $23.51^{* *}$ & $23.68 * *$ & $1836.11^{* * *}$ & $13479.58^{* * *}$ & $13479.58 * *$ & $29579.24 * *$ \\
\hline Poland & 0.05 & 5.11 & $6.68 *$ & 1.79 & 1.28 & 6.68 & $9.61^{\prime}$ \\
\hline Romania & 0.07 & 0.33 & $18.60 * *$ & 4.12 & $96.10 * *$ & $96.10 * *$ & $210.88^{* *}$ \\
\hline Russia & 2.82 & $835.20 * *$ & $7406.98 * *$ & $27.00 * *$ & $175.78^{* * *}$ & $7406.98 * *$ & $10663.07 * *$ \\
\hline South Africa & 0.03 & $20.18^{* *}$ & $18.53^{* *}$ & $21.20 * *$ & $6.99 * *$ & $21.20 * *$ & $36.45^{* *}$ \\
\hline Thailand & 0.002 & $22.06 * *$ & $271.96 * *$ & $20.96^{* *} *$ & $10.94 * *$ & $271.96 * *$ & $391.52 * *$ \\
\hline Turkey & 4.35 & 0.75 & 4.39 & $5.61 *$ & $23.14 * *$ & $23.14 * *$ & $50.78 * *$ \\
\hline Ukraine & 3.08 & $10.03 * *$ & $46.23^{* * *}$ & $8485.15^{* * *}$ & $7439.41 * *$ & $8485.15 * *$ & $16324.84 * *$ \\
\hline
\end{tabular}

Notes: $* *$ denotes statistical significance at $1 \%$ level. $*$ denotes statistical significance at $5 \%$ level. l is the number of breaks. The $5 \%$ critical values for the sup $F(l)$ test in the case where stationary and non-stationary variables are allowed are 14.53, 11.94, 10.38, 9.28 and 7.51 for $l=1,2,3,4,5$ respectively. Critical value for UDmax test is 14.79 see Kejriwal and Perron (2010). Critical value for WDmax test is 9.039 see Bai and Perron (2003-1).

Results for the sequential test of $l$ versus $l+1$ structural shifts are demonstrated in Table 6. The sequential test is designed by Bai and Perron (1998). The number of shifts is detected by using the Bayesian information criterion (BIC) and the modified Schwarz criterion (LWZ). Results indicate at least one break in all regressions with most five breaks bound, except Lithuania and Poland where null hypothesis of no structural breaks was not rejected in Table 5 . 
Table: 6

The Sequential Test Results

\begin{tabular}{|c|c|c|c|c|c|c|c|c|}
\hline Country & $\begin{array}{c}0 \\
\text { BIC }(\mathbf{L W Z})\end{array}$ & $\begin{array}{c}1 \\
\text { BIC (LWZ) }\end{array}$ & $\begin{array}{c}2 \\
\text { BIC (LWZ) }\end{array}$ & $\begin{array}{c}3 \\
\text { BIC (LWZ) }\end{array}$ & $\begin{array}{c}4 \\
\text { BIC (LWZ) }\end{array}$ & $\begin{array}{c}5 \\
\text { BIC (LWZ) }\end{array}$ & BIC & LWZ \\
\hline Argentina & $\begin{array}{c}-7.11 \\
(-7.09)\end{array}$ & $\begin{array}{c}-7.59 \\
(-7.49)\end{array}$ & $\begin{array}{c}-7.81 \\
(-7.62)\end{array}$ & $\begin{array}{c}-7.75 \\
(-7.48)\end{array}$ & $\begin{array}{c}-7.77 \\
(-7.41)\end{array}$ & $\begin{array}{c}-7.48 \\
(-7.03) \\
\end{array}$ & 2 & 2 \\
\hline Brazil & $\begin{array}{c}-8.27 \\
(-8.25)\end{array}$ & $\begin{array}{c}-8.28 \\
(-8.18)\end{array}$ & $\begin{array}{c}-8.19 \\
(-8.02)\end{array}$ & $\begin{array}{c}-8.12 \\
(-7.85)\end{array}$ & $\begin{array}{c}-8.01 \\
(-7.65)\end{array}$ & $\begin{array}{c}-7.88 \\
(-7.44)\end{array}$ & 1 & 0 \\
\hline Bulgaria & $\begin{array}{c}-5.26 \\
(-5.25)\end{array}$ & $\begin{array}{c}-5.41 \\
(-5.31)\end{array}$ & $\begin{array}{c}-5.61 \\
(-5.42) \\
\end{array}$ & $\begin{array}{c}-5.71 \\
(-5.44) \\
\end{array}$ & $\begin{array}{c}-5.82 \\
(-5.46)\end{array}$ & $\begin{array}{c}-5.74 \\
(-5.29)\end{array}$ & 4 & 4 \\
\hline Chile & $\begin{array}{c}-8.65 \\
(-8.63)\end{array}$ & $\begin{array}{c}-8.62 \\
(-8.72)\end{array}$ & $\begin{array}{c}-8.72 \\
(-8.53) \\
\end{array}$ & $\begin{array}{c}-8.75 \\
(-8.48) \\
\end{array}$ & $\begin{array}{c}-8.69 \\
(-8.33)\end{array}$ & $\begin{array}{c}-8.58 \\
(-8.13)\end{array}$ & 1 & 1 \\
\hline Colombia & $\begin{array}{c}-9.39 \\
(-9.38)\end{array}$ & $\begin{array}{c}-9.65 \\
(-9.55)\end{array}$ & $\begin{array}{c}-9.87 \\
(-9.69) \\
\end{array}$ & $\begin{array}{l}-10.06 \\
(-9.79) \\
\end{array}$ & $\begin{array}{l}-10.02 \\
(-9.66)\end{array}$ & $\begin{array}{c}-9.63 \\
(-9.18)\end{array}$ & 3 & 3 \\
\hline Estonia & $\begin{array}{c}-6.33 \\
(-6.32)\end{array}$ & $\begin{array}{c}-6.73 \\
(-6.63)\end{array}$ & $\begin{array}{c}-7.56 \\
(-7.37) \\
\end{array}$ & $\begin{array}{c}-7.65 \\
(-7.37) \\
\end{array}$ & $\begin{array}{c}-7.53 \\
(-7.17) \\
\end{array}$ & $\begin{array}{c}-7.37 \\
(-6.92)\end{array}$ & 3 & 3 \\
\hline Hungary & $\begin{array}{c}-7.06 \\
(-7.04)\end{array}$ & $\begin{array}{c}-7.31 \\
(-7.21) \\
\end{array}$ & $\begin{array}{c}-7.24 \\
(-7.06) \\
\end{array}$ & $\begin{array}{c}-7.34 \\
(-7.07) \\
\end{array}$ & $\begin{array}{c}-7.23 \\
(-6.87)\end{array}$ & $\begin{array}{c}-7.11 \\
(-6.67)\end{array}$ & 3 & 1 \\
\hline India & $\begin{array}{c}-6.41 \\
(-6.39)\end{array}$ & $\begin{array}{c}-6.67 \\
(-6.56)\end{array}$ & $\begin{array}{c}-6.67 \\
(-6.48) \\
\end{array}$ & $\begin{array}{c}-6.65 \\
(-6.38) \\
\end{array}$ & $\begin{array}{c}-6.59 \\
(-6.23)\end{array}$ & $\begin{array}{c}-6.59 \\
(-6.14)\end{array}$ & 1 & 1 \\
\hline Indonesia & $\begin{array}{c}-6.89 \\
(-6.87)\end{array}$ & $\begin{array}{c}-7.86 \\
(-7.77)\end{array}$ & $\begin{array}{c}-8.07 \\
(-7.88) \\
\end{array}$ & $\begin{array}{c}-8.49 \\
(-8.22) \\
\end{array}$ & $\begin{array}{c}-8.29 \\
(-7.93)\end{array}$ & $\begin{array}{c}-8.17 \\
(-7.72)\end{array}$ & 3 & 3 \\
\hline Lithuania & $\begin{array}{c}-6.31 \\
(-6.29)\end{array}$ & $\begin{array}{c}-6.25 \\
(-6.16)\end{array}$ & $\begin{array}{c}-6.20 \\
(-6.02) \\
\end{array}$ & $\begin{array}{c}-6.29 \\
(-6.02) \\
\end{array}$ & $\begin{array}{c}-6.28 \\
(-5.93)\end{array}$ & $\begin{array}{c}-6.26 \\
(-5.81)\end{array}$ & 0 & 0 \\
\hline Malaysia & $\begin{array}{c}-8.46 \\
(-8.44)\end{array}$ & $\begin{array}{c}-8.49 \\
(-8.40)\end{array}$ & $\begin{array}{c}-8.89 \\
(-8.71) \\
\end{array}$ & $\begin{array}{c}-8.92 \\
(-8.65) \\
\end{array}$ & $\begin{array}{c}-9.03 \\
(-8.67) \\
\end{array}$ & $\begin{array}{c}-8.79 \\
(-8.35)\end{array}$ & 4 & 2 \\
\hline Mexico & $\begin{array}{c}-9.51 \\
(-9.49)\end{array}$ & $\begin{array}{c}-9.72 \\
(-9.63)\end{array}$ & $\begin{array}{l}-10.00 \\
(-9.81) \\
\end{array}$ & $\begin{array}{c}-9.99 \\
(-9.72)\end{array}$ & $\begin{array}{c}-9.96 \\
(-9.60)\end{array}$ & $\begin{array}{c}-9.75 \\
(-9.31)\end{array}$ & 2 & 2 \\
\hline Peru & $\begin{array}{c}-7.32 \\
(-7.31)\end{array}$ & $\begin{array}{c}-7.45 \\
(-7.35)\end{array}$ & $\begin{array}{c}-7.41 \\
(-7.23) \\
\end{array}$ & $\begin{array}{c}-7.47 \\
(-7.19) \\
\end{array}$ & $\begin{array}{c}-7.43 \\
(-7.07)\end{array}$ & $\begin{array}{c}-7.33 \\
(-6.89)\end{array}$ & 3 & 1 \\
\hline Philippines & $\begin{array}{c}-7.36 \\
(-7.34)\end{array}$ & $\begin{array}{c}-7.91 \\
(-7.81)\end{array}$ & $\begin{array}{c}-8.32 \\
(-8.14) \\
\end{array}$ & $\begin{array}{c}-8.73 \\
(-8.46) \\
\end{array}$ & $\begin{array}{c}-8.76 \\
(-8.39)\end{array}$ & $\begin{array}{c}-8.64 \\
(-8.19)\end{array}$ & 4 & 3 \\
\hline Poland & $\begin{array}{c}-7.15 \\
(-7.14)\end{array}$ & $\begin{array}{c}-7.09 \\
(-6.98) \\
\end{array}$ & $\begin{array}{c}-7.08 \\
(-6.89) \\
\end{array}$ & $\begin{array}{c}-7.03 \\
(-6.76) \\
\end{array}$ & $\begin{array}{c}-6.98 \\
(-6.63)\end{array}$ & $\begin{array}{c}-6.91 \\
(-6.47)\end{array}$ & 0 & 0 \\
\hline Romania & $\begin{array}{c}-4.64 \\
(-4.62)\end{array}$ & $\begin{array}{c}-4.55 \\
(-4.45)\end{array}$ & $\begin{array}{c}-5.21 \\
(-5.02)\end{array}$ & $\begin{array}{c}-5.37 \\
(-5.10)\end{array}$ & $\begin{array}{c}-5.34 \\
(-4.98)\end{array}$ & $\begin{array}{c}-5.23 \\
(-4.78)\end{array}$ & 3 & 3 \\
\hline Russia & $\begin{array}{c}-8.28 \\
(-8.27)\end{array}$ & $\begin{array}{c}-8.42 \\
(-8.32)\end{array}$ & $\begin{array}{c}-8.83 \\
(-8.65) \\
\end{array}$ & $\begin{array}{c}-8.73 \\
(-8.46) \\
\end{array}$ & $\begin{array}{c}-8.80 \\
(-8.44)\end{array}$ & $\begin{array}{c}-8.68 \\
(-8.23)\end{array}$ & 2 & 2 \\
\hline South Africa & $\begin{array}{c}-9.78 \\
(-9.76)\end{array}$ & $\begin{array}{c}-10.28 \\
(-10.18)\end{array}$ & $\begin{array}{c}-10.69 \\
(-10.52)\end{array}$ & $\begin{array}{c}-10.72 \\
(-10.45)\end{array}$ & $\begin{array}{c}-10.64 \\
(-10.28)\end{array}$ & $\begin{array}{l}-10.42 \\
(-9.98)\end{array}$ & 3 & 2 \\
\hline Thailand & $\begin{array}{c}-8.20 \\
(-8.18)\end{array}$ & $\begin{array}{c}-8.42 \\
(-8.32)\end{array}$ & $\begin{array}{c}-8.58 \\
(-8.40)\end{array}$ & $\begin{array}{c}-8.53 \\
(-8.26)\end{array}$ & $\begin{array}{c}-8.50 \\
(-8.15)\end{array}$ & $\begin{array}{c}-8.36 \\
(-7.92)\end{array}$ & 2 & 2 \\
\hline Turkey & $\begin{array}{c}-5.82 \\
(-5.81)\end{array}$ & $\begin{array}{c}-5.79 \\
(-5.69)\end{array}$ & $\begin{array}{c}-5.91 \\
(-5.72) \\
\end{array}$ & $\begin{array}{c}-5.98 \\
(-5.72) \\
\end{array}$ & $\begin{array}{c}-6.00 \\
(-5.65)\end{array}$ & $\begin{array}{c}-5.86 \\
(-5.42)\end{array}$ & 4 & 0 \\
\hline Ukraine & $\begin{array}{c}-6.25 \\
(-6.23) \\
\end{array}$ & $\begin{array}{c}-6.63 \\
(-6.53) \\
\end{array}$ & $\begin{array}{c}-6.90 \\
(-6.72)\end{array}$ & $\begin{array}{c}-7.34 \\
(-7.06) \\
\end{array}$ & $\begin{array}{c}-7.29 \\
(-6.93) \\
\end{array}$ & $\begin{array}{c}-7.17 \\
(-6.73) \\
\end{array}$ & 3 & 3 \\
\hline
\end{tabular}

Notes: BIC - Bayesian Information Criteria, LWZ - the modified version of BIC proposed by Liu et al. (1997), are used for the selection of breaks number.

\subsection{Coefficients Estimates}

The parameters estimations under structural shifts consideration for the growth equation (2) are reported in Table 7. The dependent variable $y_{t}$ is the GDP per capita of an estimated country. The covariate $x_{t}$ is the vector of independent variables: broad money supply and trade openness. Locations of estimated break locations are reported in the last four columns $\left\{\hat{T}_{j}\right\}$. Results for estimated coefficients $\hat{\beta}_{1}$ and $\hat{\beta}_{2}$ in the presence of structural breaks are reported in the second and third columns. In most of the cases coefficients were found significant with an expected positive sign, except Hungary where the financial development coefficient is significant with a negative sign and except Bulgaria, Romania and Turkey where the trade openness coefficients are significant with a negative sign. Empirical results demonstrate a positive effect of financial development and trade openness on economic growth of estimated emerging countries. Negative effect of financial 
development on economic growth was estimated in Hungary, however value of the coefficient is low enough, -0.17 , to make any substantial conclusions. Negative effect of trade openness on economic growth was found in Bulgaria, Romania and Turkey, where values of coefficients are $-0.23,-0.58$ and -0.31 respectively. Huchet-Bourdon et al. (2011) in their study found non-linear relations between trade openness and growth in developing countries. Their empirical results illustrate that higher quality of the export basket will lead to a higher effect of trade openness on trade. If the quality of export basket is low, it can lead to a negative effect of trade openness on economic growth of developing countries.

In general, empirical results demonstrate the stronger impact of trade openness on economic growth compared to the impact of financial development in emerging countries. Thus, the altitude of trade openness coefficients for most countries was found between 0.1 and 0.4 except Romania where the trade openness coefficient is estimated at the 0.58 level with a negative sign and except Russia where the coefficient is 0.07 . Estimates of trade openness coefficients for India, Philippines and Ukraine are not significant. However, the financial development coefficient for most countries was estimated at the level between 0.1 and 0.2, except India and Malaysia where the coefficient is estimated at the 0.31 level. In cases of Brazil, Chile, Colombia and Turkey the financial development coefficient is below 0.1 and in cases of Bulgaria, Peru, Romania and Thailand the coefficient is not significant. The last four columns of the table present estimated break locations. In most countries, general tendency may be followed where most break locations are concentrated around 1997 year, which is associated with the Asian financial crisis and around period 2007-2008, which is associated with the global financial crisis. 
Table: 7

Estimated Regression Parameters in the Presence of Structural Breaks

\begin{tabular}{|c|c|c|c|c|c|c|c|c|c|c|c|}
\hline Country & $\hat{\beta}_{1}$ & $\hat{\beta}_{2}$ & $\hat{\delta}_{1}$ & $\hat{\delta}_{2}$ & $\hat{\delta}_{3}$ & $\hat{\delta}_{4}$ & $\hat{\delta}_{5}$ & $\hat{T}_{1}$ & $\hat{T}_{2}$ & $\hat{T}_{3}$ & $\hat{T}_{4}$ \\
\hline Argentina & $\begin{array}{c}0.11 * * \\
(0.03)\end{array}$ & $\begin{array}{c}0.39 * * \\
(0.04)\end{array}$ & $\begin{array}{c}3.57^{* *} * \\
(0.03)\end{array}$ & $\begin{array}{c}3.52^{* * *} \\
(0.03)\end{array}$ & $\begin{array}{c}3.57^{* *} \\
(0.04)\end{array}$ & - & - & $\begin{array}{c}\text { 2001Q3 } \\
\text { (2001Q1 - } \\
\text { 2001Q4) }\end{array}$ & $\begin{array}{c}\text { 2008Q3 } \\
(2008 \mathrm{Q} 1- \\
\text { 2009Q1) }\end{array}$ & - & - \\
\hline Brazil & $\begin{array}{l}0.05^{*} \\
(0.02)\end{array}$ & $\begin{array}{c}0.15^{* *} \\
(0.03)\end{array}$ & $\begin{array}{c}2.96^{* * *} \\
(0.02)\end{array}$ & $\begin{array}{c}2.98^{* *} \\
(0.03)\end{array}$ & - & - & - & $\begin{array}{c}\text { 2009Q1 } \\
\text { (1999Q4- } \\
\text { 2009Q3) }\end{array}$ & - & - & - \\
\hline Bulgaria & $\begin{array}{l}-0.03 \\
(0.02)\end{array}$ & $\begin{array}{c}-0.23^{*} \\
(0.08)\end{array}$ & $\begin{array}{c}3.38 * * \\
(0.13)\end{array}$ & $\begin{array}{c}3.49 * * \\
(0.13)\end{array}$ & $\begin{array}{c}3.64 * * \\
(0.15)\end{array}$ & $\begin{array}{l}3.78^{* *} \\
(0.17)\end{array}$ & $\begin{array}{l}3.85^{* * *} \\
(0.17)\end{array}$ & $\begin{array}{c}\text { 2000Q2 } \\
\text { (1999Q3- } \\
\text { 2000Q4) }\end{array}$ & $\begin{array}{c}\text { 2003Q2 } \\
(2002 Q 2- \\
\text { 2003Q4) }\end{array}$ & $\begin{array}{c}\text { 2006Q2 } \\
\text { (2005Q3 - } \\
\text { 2007Q3) }\end{array}$ & $\begin{array}{c}\text { 2010Q2 } \\
\text { (2010Q1 - } \\
\text { 2012Q4) }\end{array}$ \\
\hline Chile & $\begin{array}{c}0.09 * * \\
(0.01)\end{array}$ & $\begin{array}{c}0.16^{* *} \\
(0.01)\end{array}$ & $\begin{array}{c}8.49^{* *} \\
(0.02)\end{array}$ & $\begin{array}{c}8.51 * * \\
(0.02)\end{array}$ & - & - & - & $\begin{array}{c}\text { 2001Q3 } \\
\text { (2000Q1 - } \\
\text { 2002Q1) }\end{array}$ & - & - & - \\
\hline Colombia & $\begin{array}{c}0.07 * * \\
(0.01)\end{array}$ & $\begin{array}{c}0.15^{* *} \\
(0.02)\end{array}$ & $\begin{array}{c}8.96^{* *} * \\
(0.02)\end{array}$ & $\begin{array}{c}8.93^{* * *} \\
(0.02)\end{array}$ & $\begin{array}{c}8.94 * * \\
(0.02)\end{array}$ & $\begin{array}{c}8.96^{* *} \\
(0.02)\end{array}$ & - & $\begin{array}{c}\text { 1998Q3 } \\
\text { (1998Q2 - } \\
\text { 1998Q4) }\end{array}$ & $\begin{array}{c}2002 \mathrm{Q} 4 \\
(2002 \mathrm{Q} 3- \\
2003 \mathrm{Q} 4)\end{array}$ & $\begin{array}{c}\text { 2005Q4 } \\
\text { (2003Q4 - } \\
\text { 2006Q1) }\end{array}$ & - \\
\hline Estonia & $\begin{array}{c}0.19^{* *} \\
(0.04)\end{array}$ & $\begin{array}{c}0.35^{* *} \\
(0.04)\end{array}$ & $\begin{array}{c}3.32 * * \\
(0.04)\end{array}$ & $\begin{array}{c}3.36^{* * *} \\
(0.05)\end{array}$ & $\begin{array}{c}3.42 * * \\
(0.05)\end{array}$ & $\begin{array}{c}3.34 * * \\
(0.06)\end{array}$ & - & $\begin{array}{c}\text { 1998Q1 } \\
\text { (1997Q4 - } \\
\text { 1998Q3) }\end{array}$ & $\begin{array}{c}\text { 2001Q1 } \\
(2000 \mathrm{Q} 4- \\
\text { 2001Q2) }\end{array}$ & $\begin{array}{c}\text { 2008Q4 } \\
\text { (2008Q3 - } \\
\text { 2009Q1) }\end{array}$ & \\
\hline Hungary & $\begin{array}{c}-0.17 * * \\
(0.07)\end{array}$ & $\begin{array}{c}0.23 * * \\
(0.06)\end{array}$ & $\begin{array}{c}8.50^{* * *} \\
(0.09)\end{array}$ & $\begin{array}{c}8.56^{* * *} \\
(0.09)\end{array}$ & $\begin{array}{l}8.62 * * \\
(0.10)\end{array}$ & $\begin{array}{c}8.66^{* *} \\
(0.11)\end{array}$ & - & $\begin{array}{c}\text { 1998Q2 } \\
\text { (1997Q1 - } \\
\text { 1998Q4) }\end{array}$ & $\begin{array}{c}\text { 2001Q1 } \\
(2000 Q 3- \\
\text { 2002Q2) }\end{array}$ & $\begin{array}{c}2005 \mathrm{Q} 1 \\
(2004 \mathrm{Q} 3- \\
\text { 2006Q3) }\end{array}$ & - \\
\hline India & $\begin{array}{c}0.31 * * \\
(0.06)\end{array}$ & $\begin{array}{l}-0.01 \\
(0.06)\end{array}$ & $\begin{array}{c}6.12 * * \\
(0.07)\end{array}$ & $\begin{array}{c}6.21^{* * *} \\
(0.08)\end{array}$ & - & - & - & $\begin{array}{c}\text { 2005Q2 } \\
(2004 Q 3- \\
\text { 2005Q4) }\end{array}$ & - & - & - \\
\hline Indonesia & $\begin{array}{c}0.15^{* *} \\
(0.03)\end{array}$ & $\begin{array}{c}0.23 * * \\
(0.02)\end{array}$ & $\begin{array}{c}8.85^{* *} * \\
(0.04)\end{array}$ & $\begin{array}{c}8.74 * * \\
(0.05)\end{array}$ & $\begin{array}{c}8.77^{* * *} \\
(0.05)\end{array}$ & $\begin{array}{c}8.82^{* *} \\
(0.06)\end{array}$ & - & $\begin{array}{c}\text { 1998Q1 } \\
\text { (1997Q4 - } \\
\text { 1998Q2) }\end{array}$ & $\begin{array}{c}\text { 2001Q2 } \\
(2000 Q 4- \\
\text { 2001Q3) }\end{array}$ & $\begin{array}{c}2008 \mathrm{Q} 4 \\
(2008 \mathrm{Q} 3- \\
\text { 2009Q1) }\end{array}$ & - \\
\hline Lithuania & - & - & - & - & - & - & - & - & - & - & - \\
\hline Malaysia & $\begin{array}{c}0.31 * * \\
(0.02)\end{array}$ & $\begin{array}{c}0.12 * * \\
(0.03)\end{array}$ & $\begin{array}{c}0.52^{* * *} \\
(0.03)\end{array}$ & $\begin{array}{c}0.48^{* * *} \\
(0.03)\end{array}$ & $\begin{array}{c}0.50^{* * *} \\
(0.03)\end{array}$ & - & - & $\begin{array}{c}1997 Q 4 \\
\text { (1995Q2 - } \\
1999 Q 2)\end{array}$ & $\begin{array}{c}\text { 2002Q1 } \\
\text { (1998Q4 - } \\
\text { 2008Q1) }\end{array}$ & - & - \\
\hline Mexico & $\begin{array}{l}0.11 * * \\
(0.01)\end{array}$ & $\begin{array}{l}0.10^{* * *} \\
(0.02)\end{array}$ & $\begin{array}{c}4.65^{* *} \\
(0.01)\end{array}$ & $\begin{array}{c}4.63 * * \\
(0.01)\end{array}$ & $\begin{array}{c}4.60 * * \\
(0.01)\end{array}$ & - & - & $\begin{array}{c}\text { 2001Q1 } \\
(2000 \mathrm{Q} 2- \\
\text { 2002Q2) }\end{array}$ & $\begin{array}{c}2008 \mathrm{Q} 4 \\
\text { (2008Q2 - } \\
\text { 2010Q1) }\end{array}$ & & \\
\hline Peru & $\begin{array}{c}0.04 \\
(0.04)\end{array}$ & $\begin{array}{c}0.15^{* *} \\
(0.04)\end{array}$ & $\begin{array}{c}3.04 * * \\
(0.08)\end{array}$ & $\begin{array}{c}3.07 * * * \\
(0.08)\end{array}$ & $\begin{array}{c}3.13 * * \\
(0.09)\end{array}$ & $\begin{array}{l}3.11^{* *} \\
(0.09)\end{array}$ & - & $\begin{array}{c}\text { 2002Q1 } \\
(2000 \mathrm{Q} 4- \\
\text { 2002Q4) }\end{array}$ & $\begin{array}{c}\text { 2007Q1 } \\
(2006 \mathrm{Q} 3- \\
\text { 2007Q3) }\end{array}$ & $\begin{array}{c}\text { 2009Q4 } \\
\text { (2005Q1 - } \\
\text { 2013Q1) }\end{array}$ & \\
\hline Philippines & $\begin{array}{l}0.17 * * \\
(0.03)\end{array}$ & $\begin{array}{c}0.02 \\
(0.03)\end{array}$ & $\begin{array}{c}3.26 * * \\
(0.09)\end{array}$ & $\begin{array}{c}3.24 * * \\
(0.09)\end{array}$ & $\begin{array}{c}3.28 * * \\
(0.09)\end{array}$ & $\begin{array}{c}3.32^{* * *} \\
(0.09)\end{array}$ & $\begin{array}{c}3.34 * * \\
(0.09)\end{array}$ & $\begin{array}{c}\text { 1997Q4 } \\
\text { (1997Q4 - } \\
\text { 1997Q4) }\end{array}$ & $\begin{array}{c}\text { 2003Q3 } \\
\text { (2002Q1 - } \\
\text { 2008Q3) }\end{array}$ & $\begin{array}{c}\text { 2006Q4 } \\
\text { (2006Q1 - } \\
\text { 2011Q1) }\end{array}$ & $\begin{array}{c}\text { 2009Q4 } \\
\text { (2008Q2 - } \\
\text { 2010Q3) }\end{array}$ \\
\hline Poland & - & - & - & - & - & - & - & - & - & - & - \\
\hline Romania & $\begin{array}{l}-0.01 \\
(0.04)\end{array}$ & $\begin{array}{c}-0.58^{* * *} \\
(0.09)\end{array}$ & $\begin{array}{c}4.24 * * \\
(0.11)\end{array}$ & $\begin{array}{c}4.38^{* * *} \\
(0.12)\end{array}$ & $\begin{array}{c}4.59 * * \\
(0.13)\end{array}$ & $\begin{array}{c}4.79 * * \\
(0.14)\end{array}$ & - & $\begin{array}{c}\text { 2000Q2 } \\
\text { (1998Q4 - } \\
\text { 2000Q3) }\end{array}$ & $\begin{array}{c}\text { 2003Q2 } \\
\text { (2002Q3 - } \\
\text { 2003Q4) }\end{array}$ & $\begin{array}{c}\text { 2006Q2 } \\
\text { (2005Q1 - } \\
\text { 2007Q1) }\end{array}$ & - \\
\hline Russia & $\begin{array}{c}0.21 * * \\
(0.01)\end{array}$ & $\begin{array}{c}0.07 * * \\
(0.02)\end{array}$ & $\begin{array}{c}4.86^{* * *} \\
(0.02)\end{array}$ & $\begin{array}{c}4.81 * * \\
(0.01)\end{array}$ & $\begin{array}{c}4.78^{* * *} \\
(0.01)\end{array}$ & - & - & $\begin{array}{c}\text { 1997Q4 } \\
\text { (1997Q3 - } \\
\text { 2001Q3) }\end{array}$ & $\begin{array}{c}\text { 2009Q1 } \\
(2008 Q 4- \\
\text { 2009Q4) }\end{array}$ & & \\
\hline $\begin{array}{l}\text { South } \\
\text { Africa }\end{array}$ & $\begin{array}{c}0.16^{* *} \\
(0.01)\end{array}$ & $\begin{array}{c}0.10^{* *} \\
(0.01)\end{array}$ & $\begin{array}{c}4.15^{* *} \\
(0.02)\end{array}$ & $\begin{array}{c}4.12^{* * *} \\
(0.02)\end{array}$ & $\begin{array}{c}4.12^{* *} \\
(0.02)\end{array}$ & $\begin{array}{l}4.13^{* *} \\
(0.02)\end{array}$ & - & $\begin{array}{c}\text { 1997Q3 } \\
\text { (1997Q2 - } \\
\text { 1998Q2) }\end{array}$ & $\begin{array}{c}\text { 2002Q3 } \\
\text { (1996Q3 - } \\
\text { 2003Q1) }\end{array}$ & $\begin{array}{c}2006 \mathrm{Q} 1 \\
(2005 \mathrm{Q} 1- \\
\text { 2008Q4) }\end{array}$ & \\
\hline Thailand & $\begin{array}{c}0.04 \\
(0.04)\end{array}$ & $\begin{array}{c}0.36 * * \\
(0.02)\end{array}$ & $\begin{array}{c}4.44 * * \\
(0.05)\end{array}$ & $\begin{array}{c}4.41^{* * *} \\
(0.06)\end{array}$ & $\begin{array}{c}4.44^{* * *} \\
(0.06)\end{array}$ & - & - & $\begin{array}{c}\text { 1998Q1 } \\
\text { (1997Q4 - } \\
\text { 2001Q2) }\end{array}$ & $\begin{array}{c}2001 \mathrm{Q} 3 \\
(2000 \mathrm{Q} 2- \\
\text { 2001Q4) }\end{array}$ & & \\
\hline Turkey & $\begin{array}{l}0.07 * \\
(0.03)\end{array}$ & $\begin{array}{c}-0.31^{* *} \\
(0.09)\end{array}$ & $\begin{array}{c}3.69^{* *} \\
(0.13) \\
\end{array}$ & $\begin{array}{c}3.65 * * \\
(0.13) \\
\end{array}$ & $\begin{array}{c}3.76^{* * *} \\
(0.15) \\
\end{array}$ & $\begin{array}{c}3.84^{* * *} \\
(0.16) \\
\end{array}$ & $\begin{array}{c}3.92 * * \\
(0.16)\end{array}$ & $\begin{array}{c}\text { 1998Q4 } \\
\text { (1995Q1 - } \\
\text { 2001Q1) }\end{array}$ & $\begin{array}{c}\text { 2003Q2 } \\
\text { (2001Q4- } \\
\text { 2004Q1) }\end{array}$ & $\begin{array}{c}\text { 2006Q1 } \\
\text { (2003Q3 - } \\
\text { 2008Q3) }\end{array}$ & $\begin{array}{c}2010 \mathrm{Q} 3 \\
\text { (2010Q3 - } \\
\text { 2013Q2) }\end{array}$ \\
\hline Ukraine & $\begin{array}{c}0.15^{* *} \\
(0.02)\end{array}$ & $\begin{array}{c}0.06 \\
(0.04)\end{array}$ & $\begin{array}{c}3.56^{* * *} \\
(0.05)\end{array}$ & $\begin{array}{c}3.51^{* * *} \\
(0.05)\end{array}$ & $\begin{array}{c}3.39 * * \\
(0.05)\end{array}$ & $\begin{array}{c}3.48^{* *} \\
(0.06)\end{array}$ & - & $\begin{array}{c}\text { 1998Q3 } \\
\text { (1997Q3 - } \\
\text { 1998Q4) }\end{array}$ & $\begin{array}{c}\text { 2002Q1 } \\
(2000 \mathrm{Q} 4- \\
2002 \mathrm{Q} 2)\end{array}$ & $\begin{array}{c}\text { 2004Q4 } \\
\text { (2003Q3 - } \\
\text { 2006Q3) }\end{array}$ & - \\
\hline
\end{tabular}

Notes: The parentheses under the break points are $95 \%$ confidence intervals for the break dates. Coefficients $\beta_{1}$, $\beta_{2}, \delta_{1}, \delta_{2}, \delta_{3}, \delta_{4}$ and $\delta_{5}$ are from equation $2 .{ }^{* *}$, ${ }^{*}$ Denote statistical significance at the 1 and $5 \%$ level respectively. 


\subsection{Cointegration}

The results of the Gregory and Hansen (1996) cointegration test are reported in Table 8. The test is applied to regressions where one structural break was detected by one of information criterion, BIC or LWZ, Brazil, Chile, Hungary, India and Peru. A structural shift is allowed in both intercept and in the slope of the model. The results of the ADF*, $\mathrm{Z}_{t}^{*}$, and $\mathrm{Z}_{\alpha} *$ statistics provide enough evidence to conclude that cointegration relations exist in growth equations of all estimated countries in the presence of one structural break.

Table: 8

Cointegration Test with a Structural Break Gregory and Hansen

\begin{tabular}{|l|c|c|c|}
\hline Country & ADF* & $Z_{t}^{*}$ & $Z_{\alpha}^{*}$ \\
\hline Brazil & -5.63 & $-8.86^{* *}$ & $-68.71^{*}$ \\
\hline Chile & -2.78 & $-8.33^{* *}$ & $-73.61^{*}$ \\
\hline Hungary & -3.89 & $-9.82^{* *}$ & $-84.24^{* *}$ \\
\hline India & -5.04 & $-8.35^{* *}$ & $-71.13^{*}$ \\
\hline Peru & -5.47 & $-11.73^{* *}$ & $-99.28^{* *}$ \\
\hline
\end{tabular}

Notes: * denotes statistical significance at 5\% level. ** denotes statistical significance at $1 \%$ level. The critical values are collected from Gregory and Hansen (1996), Table 1, and for 2 independent variables are -6.45, -5.96 and -5.72 (1\%, 5\% and 10\%) for ADF and Zt tests, and are -79.65, -68.43 and -63.10 (1\%, 5\% and $10 \%)$.

Next, the Hatemi-J (2008) test, Table 9, is applied to countries where the Kejriwal and Perron $(2008,2010)$ test detected two structural shifts. The test is employed for Argentina, Malaysia, Mexico, Russia, South Africa and Thailand. The null hypothesis of no cointegration is not rejected in cases of Malaysia, South Africa and Thailand and at least one of the tests rejects the hypothesis of no cointegration at the five percent significance level in cases of Argentina, Mexico and Russia. The empirical results suggest cointegration relationships only in cases of Argentina, Mexico and Russia in the presence of two structural breaks. The Hatemi-J (2008) test detected two possible break locations for every country. Break locations of the test are consistent in general with break locations detected by the Kejriwal and Perron $(2008,2010)$ tests in Table 7. First break locations are concentrated around the years 1997-2000. These years are characterized by the Asian financial crisis and by its negative impact on emerging countries in subsequent years. Second break locations are diverse but none of them cover global financial crisis and take place in the years 20012005 , which are characterized by internal economic instability in emerging countries. 
Table: 9

The Hatemi-J (2008) Cointegration Test

\begin{tabular}{|c|c|c|c|c|}
\hline Country & Model & ADF* & $Z_{t}^{*}$ & $Z_{\alpha}^{*}$ \\
\hline \multirow[t]{3}{*}{ Argentina } & $\mathrm{C} / \mathrm{S}$ & -5.04 & $-12.20 * *$ & $-109.44^{* *}$ \\
\hline & 1 & 1999Q3 & 1999Q3 & 2001Q3 \\
\hline & 2 & $2004 \mathrm{Q} 3$ & 2003Q1 & 2006Q1 \\
\hline \multirow[t]{3}{*}{ Malaysia } & $\mathrm{C} / \mathrm{S}$ & -5.07 & -6.26 & -51.95 \\
\hline & 1 & 2000Q3 & 1998Q1 & 1998Q1 \\
\hline & 2 & $2002 \mathrm{Q} 1$ & 2001Q3 & 2001Q3 \\
\hline \multirow[t]{3}{*}{ Mexico } & $\mathrm{C} / \mathrm{S}$ & -5.72 & $-8.50 * *$ & -71.12 \\
\hline & 1 & 2000Q3 & 1998Q4 & 1998Q4 \\
\hline & 2 & 2006Q2 & 2005Q4 & 2005Q4 \\
\hline \multirow[t]{3}{*}{ Russia } & $\mathrm{C} / \mathrm{S}$ & -6.39 & $-6.45^{*}$ & -53.98 \\
\hline & 1 & 1998Q1 & 1998Q1 & 1998Q1 \\
\hline & 2 & 2003Q4 & 2003Q4 & 2003Q4 \\
\hline \multirow[t]{3}{*}{ South Africa } & $\mathrm{C} / \mathrm{S}$ & -5.46 & -5.61 & -46.60 \\
\hline & 1 & 2002Q1 & 1997Q4 & 1997Q4 \\
\hline & 2 & 2006Q1 & 2001Q4 & 2001Q4 \\
\hline \multirow[t]{3}{*}{ Thailand } & $\mathrm{C} / \mathrm{S}$ & -5.66 & -5.52 & -43.26 \\
\hline & 1 & 2001Q1 & 1997Q4 & 1997Q3 \\
\hline & 2 & 2005Q2 & 1998Q3 & 1998Q3 \\
\hline
\end{tabular}

Notes: The critical values are collected from Hatemi-J (2008) and for 2 independent variables are -6.928, -6.458 and $-6.224(1 \%, 5 \%$ and $10 \%)$ for $A D F$ and $\mathrm{Zt} \mathrm{tests,} \mathrm{and} \mathrm{are}-99.458,83.644$ and $76.806(1 \%, 5 \%$ and $10 \%)$.

\section{Table: 10}

\section{The Maki (2012) Cointegration Test}

\begin{tabular}{|c|c|c|c|c|c|}
\hline Country & MB1 & MB2 & MB3 & MB4 & MB5 \\
\hline Argentina & $-12.44 *$ & $-14.34 *$ & $-14.72 *$ & $-15.34 *$ & $-15.52 *$ \\
\hline Brazil & $-8.41^{*}$ & $-8.69^{*}$ & $-8.98 *$ & $-9.82 *$ & $-10.75 *$ \\
\hline Bulgaria & $-7.21 *$ & $-8.09^{*}$ & $-8.52 *$ & $-9.31 *$ & $-9.31 *$ \\
\hline Chile & $-11.39 *$ & $-13.51 *$ & $-13.89 *$ & $-13.89 *$ & $-13.89 *$ \\
\hline Colombia & -5.04 & $-6.64 *$ & $-7.53 *$ & $-7.94 *$ & $-8.52 *$ \\
\hline Estonia & $-10.50 *$ & $-12.47 *$ & $-13.39 *$ & $-13.39 *$ & $-13.39 *$ \\
\hline Hungary & $-7.04 *$ & $-7.45^{*}$ & $-7.55^{*}$ & $-8.49 *$ & $-8.49^{*}$ \\
\hline India & -5.60 & -5.60 & $-8.44 *$ & $-10.23^{*}$ & $-10.61 *$ \\
\hline Indonesia & $-7.84^{*}$ & $-8.68^{*}$ & $-9.13^{*}$ & $-10.85^{*}$ & $-12.39 *$ \\
\hline Malaysia & $-6.75^{*}$ & $-6.75^{*}$ & -6.75 & $-8.35 *$ & $-8.52 *$ \\
\hline Mexico & $-6.25^{*}$ & $-7.73^{*}$ & $-7.93 *$ & $-9.28 *$ & $-10.04 *$ \\
\hline Peru & $-10.45 *$ & $-10.45 *$ & $-10.45^{*}$ & $-10.45^{*}$ & $-10.45 *$ \\
\hline Philippines & -4.45 & -5.26 & -6.95 & -6.95 & -6.95 \\
\hline Romania & -5.64 & -6.55 & -6.55 & -7.33 & $-8.18^{*}$ \\
\hline Russia & $-6.77 *$ & -6.77 & -6.77 & $-7.89 *$ & $-8.59 *$ \\
\hline South Africa & -4.38 & -4.38 & -4.39 & -6.36 & -7.33 \\
\hline Thailand & -4.95 & -5.64 & -6.11 & -6.11 & -6.11 \\
\hline Turkey & $-6.84^{*}$ & $-6.84^{*}$ & $-7.24 *$ & $-9.02 *$ & $-10.52 *$ \\
\hline Ukraine & $-6.28 *$ & -6.28 & $-7.88 *$ & $-8.41 *$ & $-8.91 *$ \\
\hline
\end{tabular}

Notes: * denotes statistical significance at the $5 \%$ level. Critical values are taken from Maki (2012) - Table 1. The critical values for 2 regressor for trend and regime shifts model with 5\% significance level are -6.055, -6.657, $7.145,-7.636,-8.129$ for 5 structural breaks respectively for trend and regime shifts model. The trimming parameter is 0.05 .

Table 10 reports results for the Maki (2012) test, which was employed to all countries exhibit structural shifts. $M B k$ denotes $t$-statistics of the Maki test where $k$ is the maximum number of shifts and it can vary from one to five. The results imply that cointegration relationships exist in all countries when unknown multiple shifts are allowed, except Philippines, South Africa and Thailand. The test statistics are consistent with the Gregory and Hansen and the Hatemi-J tests results when one and two shifts are allowed. Only in the case of India, the Maki test failed to reject the null hypothesis of no cointegration when one shift is allowed, and in case of Malaysia, the Maki test, opposite to the Hatemi-J test, rejected the null hypothesis of no cointegration when two shifts are allowed. Thus, the test results 
reveal the presence of long-term relationships in most of estimated countries except Philippines, South Africa and Thailand when multiple structural breaks are allowed.

\section{Conclusion}

This study investigated cointegration relations between economic growth, financial development and trade openness in emerging markets in the presence of structural breaks. 21 emerging countries were estimated for the 1995-2013 period on a quarterly basis. First of all, the Perron and Yabu (2009) test was applied to test for structural shifts in employed time series (Table 1). To investigate the order of integration of variables, two different unit root tests were employed. Firstly, the $\mathrm{Ng}$ and Perron (2001) test, Table 2, was applied to variables that have not been exposed to structural. Secondly, the Carrion-i-Silvestre et al. (2009) unit root test, Table 3, was applied to variables where the presence of structural breaks was detected. The results of unit root tests provided evidence to conclude that variables in use are of mixed integration order when structural breaks are allowed in estimations.

Taking into account the mixed integration order of variables, the Kejriwal and Perron $(2008,2010)$ procedure was employed in order to test the existence of structural breaks in growth equation (1). The results of the procedure, Tables 5, 6 and 7, indicate the existence of at least one break in the growth equation (1) of emerging countries except Lithuania and Poland. Estimations of coefficients in the presence of structural breaks, Table 7, illustrate the stronger impact of trade openness on economic development of emerging countries compared to the impact of financial development. Estimations of structural break locations illustrate that most of the detected break locations in estimated emerging countries are concentrated around Asian financial crisis of 1997 and the global financial crisis 2007-2008.

The presence of structural shifts in the series requires further estimations by tests that allow for changes. Firstly, the Gregory and Hansen (1996) test that allows for one structural break was applied to Brazil, Chile, Hungary, India and Peru, Table 8. The results of the test illustrate the existence of cointegration relations among series in indicated countries. Secondly, the Hatemi-J (2008) test, Table 9 was applied to countries where two structural breaks were found. These countries are Argentina, Malaysia, Mexico, Russia, South Africa and Thailand. The test results supported the existence of cointegration relations between series in Argentina, Mexico and Russia and failed to do so in cases of Malaysia, South Africa and Thailand. Finally, the Maki (2012) test, Table 10, was employed to all cases where structural shifts were detected. Table 10 presents the test statistics when up to five structural shifts are allowed. The Maki test found cointegration relationships in growth equation in most countries. The results of the Maki test are consistent with results of the Gregory and Hansen test, when one shift is allowed, except India. The Maki test failed to reject the null hypothesis of no cointegration when one shift is allowed in case of India. In the case when two shifts are allowed, results of the Maki test are consistent with the Hatemi-J test for all five estimated countries except Malaysia where the Maki test found evidence of cointegration. 
Aydoğan, E.T. \& Ç.L. Uslu \& N. Ketenci (2017), "Determinants of Economic Growth in Emerging Countries Under Structural Breaks Consideration”, Sosyoekonomi, Vol. 25(33), 37-58.

The main outcome of this study is the existence of long-run relationships between growth, financial development and trade openness in emerging countries except Philippines, South Africa and Thailand. Cointegration was found in all countries when structural shifts where not considered in the model, Table 4. However, consideration of structural shifts in estimations provided slightly different results where cointegration relationships were found not in all countries. Therefore, when estimations with uncounted structural breaks provide evidence for cointegration relationships in all countries, results have to be interpreted with caution. To the knowledge of the authors, no other studies on basic determinants of economic growth in emerging countries have probed into the topic using recent econometric tools related to structural breaks. Most of studies on this topic focused on causality issues between economic growth and its determinants. Results concerning determinants of economic growth in the literature are varying with sample size, sample countries and employed econometric technique. Therefore, it is no leading conclusion on determinants of economic growth in the literature. Menyah et al (2014) for example found little evidence for concluding that economic growth in 21 African countries is led by financial development and trade factors. In case of Bolivia, Bojanic (2012) it was found that economic growth is led by both financial development and trade openness. Finally, Shahbaz (2012), similar to results of this study, found evidence to support the growth-led- trade hypothesis indicating that trade openness promotes economic growth and is more important determinant than financial development in the case of Pakistan.

Results of this study revealed that trade openness is a more effective determinant of economic growth in emerging countries in the presence of structural breaks. However, it may be wrong to conclude that governments of emerging countries have to pay more attention to trade openness than to financial development. Without financial growth, domestic industries of emerging economies may have difficulties in building competitiveness at the international level, therefore trade openness has to be the focus for emerging economies however with the support of financial development.

\section{References}

Agbetsiafia, D. (2004), "The finance growth nexus: evidence from Sub-Saharan Africa", Sav. Dev. 28(3), 271-288.

Al-Malkawi, H.A.N. \& H.A. Marashdeh (2012), "Financial Development and Economic Growth in the UAE: Empirical Asssessment Using ARDL Approach to Co-integration", International Journal of Economics and Finance, 4(5), 105-115.

Andrews, D.W.K. \& W. Ploberger (1994), "Optimal tests when a nuisance parameter is present only under the alternative", Econometrica, 62, 1383-1414.

Ang, J. (2007), "A Survey of Recent Developments in the Literature of Finance and Growth", Monash University Business and Economics, Discussion Paper 03/07, ISSN 1441-5429.

Ansari, M.I. (2002), "Impact of financial development, money, and public sending on Malaysian National Income: an econometric study", Journal of Asian Economics, 13, 72-93.

Arestis, P. (2002), "The impact of financial liberalization policies on financial development: evidence from developing economies", International Journal of Finance and Economics, 7, 109-21. 
Aydoğan, E.T. \& Ç.L. Uslu \& N. Ketenci (2017), "Determinants of Economic Growth in Emerging Countries Under Structural Breaks Consideration”, Sosyoekonomi, Vol. 25(33), 37-58.

Arestis, P. \& P. Demetriades \& K. Luintel (2001), "Financial development and economic growth: the role of stock markets", Journal of Money, Credit, and Banking, 33, 16-41.

Atje, R. \& B. Jovanovic (1993), "Stock Markets and Development”, European Economic Review, 37, 632-640.

Bai, J. \& P. Perron (1998), "Estimating and testing linear models with multiple structural changes", Econometrica, 66, 47-68.

Bai, J. \& P. Perron (2003), "Computation and analysis of multiple structural change models", Journal of Applied Econometrics, 18, 1-22.

Bojanic, A.N. (2012), "The impact of financial development and trade on the economic growth of Bolivia", Journal of Applied Economics, 15(1), 51-70.

Carrion-i-Silvestre, J.Ll. \& D. Kim \& P. Perron (2009), "GLS-based unit root tests with multiple structural breaks under both the null and the alternative hypotheses", Econometric Theory, 25, 1754-1792.

Chimobi, O.P. (2010), "The Causal Relationship among Financial Development, Trade Openness and Economic Growth in Nigeria", International Journal of Economics and Finance, 2(2), 137-147.

Christopoulos, D.K. \& E.G. Tsionas (2004), "Financial Development and Economic Growth: Evidence from Panel Unit Root and Cointegration Tests", Journal of Development Economics, 73, 55-74.

Demetriades, P.O. \& K.A. Hussein (1996), "Does Financial Development Cause Economic Growth? Time-series Evidence from 16 Countries", Journal of Development Economics, 51, 387411.

Elliot, G. \& T.J. Rothenberg \& J.H. Stock (1996), "Efficient tests for an autoregressive unit root", Econometrica, 64, 813-836.

Evans, A.D. \& C. Green \& V. Murinde (2002), "Human capital and financial development in economic growth: New evidence using the translog production function", International Journal of Finance and Economics, 17, 123-40.

Federici, D. \& F. Caprioli (2009), "Financial Development and Growth: An Empirical Analysis", Economic Modelling, 26, 285-294.

Halıcioglu, F. (2007), “The Financial Development and Economic Growth nexus for Turkey”, Working Papers, No. 2007/6, Economics and Econometrics Research Institute, Brussels, Belgium.

Hatemi-J, A. (2008), "Tests for cointegration with two unknown regime shifts with an application to financial market integration", Empirical Economics, 35(3), 497-505.

Huchet-Bourdon, M. \& L.C. Mouel \& M. Vijil (2011), "The Relationship between Trade Openness and Economic Growth: Some New Insights on the Openness Measurement Issue", XIIIeme Congres de I'Association Europeenne des Economistes Agricoles (EAAE), 1-17.

Hsueh, S.-J. \& Y.-H. Hu \& C.-H. Tu (2013), "Economic Growth and Financial Development in Asian Countries: A Bootstrap Panel Granger Causality Analysis", Economic Modelling, 32, 294-301.

Goldsmith, R.W. (1969), Financial Structure and Development, New Haven, CT: Yale University Press.

Gregory, A.W. \& B.E. Hansen (1996), "Tests for cointegration in models with trend and regime shifts", Oxford Bulletin for Economics and Statistics, 58(3), 555-560. 
Aydoğan, E.T. \& Ç.L. Uslu \& N. Ketenci (2017), "Determinants of Economic Growth in Emerging Countries Under Structural Breaks Consideration”, Sosyoekonomi, Vol. 25(33), 37-58.

Jalilian, H. \& C. Kirkpatrick (2002), "Financial development and poverty reduction in developing countries", International Journal of Finance and Economics, 7, 97-108.

Kapetanios, G. (2005), "Unit-root testing against the alternative hypothesis of up to m structural breaks", Journal of Time Series Analysis, 26, 123-133.

Kar, M. \& S. Nazlığlu \& H. Ağır (2011), "Financial Development and Economic Growth Nexus in the MENA Countries: Bootstrap Panel Granger Causality Analysis", Economic Modelling, 28(1-2), 685-693.

Kar, M. \& O. Peker \& M. Kaplan (2008), “Trade Liberalization, Financial Development and Economic Growth in the Long Term: The Case of Turkey", South East European Journal of Economics and Business, 3(2), 12-22.

Kejriwal. M. \& P. Perron (2008), "The limit distribution of the estimates in cointegrated regression models with multiple structural changes", Journal of Econometrics, 146(1), 59-73.

Kejriwal. M. \& P. Perron (2010), "Testing for multiple structural changes in cointegrated regression models", Journal of Business and Economic Statistics, 28(4), 503-522.

Kemal, A.R. \& A. Quayyum \& M.N. Hanif (2004), "Financial Development and Economic Growth: Evidence from a Heterogeneous Panel of High Income Countries", MPRA Paper No. 10198, <http://mpra.ub.uni-muenchen.de/10198>, 27.08.2008.

Ketenci, N. (2016), "The bilateral trade flows of the EU in the presence of structural breaks", Empirical Economics, 51(4), 1369-1398.

Kim, D. \& P. Perron (2009), "Unit root test allowing for a break in the trend function under both the null and alternative hypothesis", Journal of Econometrics, 148, 1-13.

Kim, D.H. \& S.C. Lin \& Y.B. Suen (2010), "Dynamic Effects of Trade Openness on Financial Development", Economic Modelling, 27(1), 254-261.

King, R.G. \& R. Levine (1993a), "Finance and Growth: Schumpeter Might be Right”, Quarterly Journal of Economics, 108, 717-737.

King, R.G. \& R. Levine (1993b), "Finance, Entrepreneurship and Growth", Journal of Monetary Economics, 32, 30-71.

Levine, R. \& S. Zervos (1998), "Stock Markets, Banks, and Economic Growth”, American Economic Review, 88, 537-558.

Levine, R. (2003), Finance and Economic Growth: Theory, Evidence and Mechanism, an unpublished paper.

Liang, Q. \& J.Z. Teng (2006), "Financial Development and Economic Growth: Evidence from China”, China Economic Review, 17, 395-411.

Liu, J. \& S. Wu \& J.V. Zidek (1997), “On segmented multivariate regressions”, Statistica Sinica, 7, 497-525.

Lucas, R.E. (1988), “On the Mechanics of Economic Development”, Journal of Monetary Economics, 22, 3-42.

Luintel, K. \& M. Khan (1999), “A quantitative reassessment of the finance-growth nexus: Evidence from a multivariate VAR", Journal of Development Economics, 60, 381-405.

Maki, D. (2012), "Tests for cointegration allowing for an unknown number of breaks", Economic Modelling, 29(5), 2011-2015.

Menyah, K. \& S. Nazlioglu \& Y. Wolde-Rufael (2014), "Financial development, trade openness and economic growth in African countries: New insights from a panel causality approach", Economic Modelling, 37, 386-394. 
Aydoğan, E.T. \& Ç.L. Uslu \& N. Ketenci (2017), "Determinants of Economic Growth in Emerging Countries Under Structural Breaks Consideration”, Sosyoekonomi, Vol. 25(33), 37-58.

Ng, S. \& P. Perron (2001), "Lag selection and the construction of unit root tests with good size and power", Econometrica, 69, 1519-1554.

Omoke, P.C. (2010), "The casual relationship among financial development, trade openness and economic growth in Nigeria", International Journal of Economics and Finance, 2(2), 137-147.

Patrick, H.T. (1966), "Financial Development and Economic Growth in Underdeveloped Countries", Economic Development and Cultural Change, 14, 174-189.

Perron, P. \& S. Ng (1996), "Useful modifications to some unit root tests with dependent errors and their local asymptotic properties", Review of Economic Studies, 63, 435-463.

Perron, P. \& T. Vogelsang (1992), "Nonstationarity and level shifts with an application to purchasing power parity", Journal of Business \& Economic Statistics, 10, 301-320.

Perron, P. (1997), "Further evidence on breaking trend functions in macroeconomic variables", Journal of Econometrics, 80, 355-385.

Perron, P. \& T. Yabu (2009), "Testing for shifts in trend with an integrated or stationary noise component", Journal of Business and Economics Statistics, 27, 369-96.

Rajan, R.G. \& L. Zingales (1998), "Financial dependence and growth", American Economic Review, $88,559-86$.

Robinson, J. (1952), The Generalization of General Theory, The Rate of Interest and Other Essays, Macmillan, London, 67-142.

Romer, P.M. (1986), "Increasing Returns and Long-Run Growth”, Journal of Political Economy, 94, 1002-1037.

Roubini, N. \& X. Sala-i-Martin (1991), "Financial Development, Trade Regimes and Economic Growth", NBER Working Paper, No. 3876, October.

Schumpeter, J.A. (1934), The Theory of Economic Development: An Inquiry into Profits, Capital, Credit, Interest, and the Business Cycle, translated by Redvers Opie, Cambridge, MA: Harvard University Press.

Shan, J. \& Q. Jianhong (2006), “Does Financial Development 'Lead' Economic Growth? The Case of China", Annals of Economics and Finance, 1, 197-216.

Shan, J.Z. \& A. Morris (2002), "Does financial development 'lead' economic growth?", International Review of Applied Economics, 16, 153-68.

Shahbaz, M. (2012), "Does trade openness affect long run growth? Cointegration, causality and forecast error variance decomposition tests for Pakistan”, Economic Modelling, 29(6), 2325-2339.

Uddin, G.S. \& B. Sjö \& M. Shahbaz (2013), "The Causal Nexus between Financial Development and Economic Growth in Kenya", Economic Modelling, 35, 701-707.

Vogelsang, T.J. \& P. Perron (1998), “Additional Tests for a Unit Root Allowing for a Break in the Trend Function at an Unknown Time", Inter-national Economic Review, 39, 1073-1100.

Wang, E.C. (2000), "A dynamic two-sector model for analyzing the interrelation between financial development and industrial growth", International Review of Economics and Finance, 9, 223-41.

Zivot, E. \& D. Andrews (1992), "Further evidence of great crash, the oil price shock and unit root hypothesis", Journal of Business and Economic Statistics, 10(3), 251-270.

Yang, Y.Y. \& M.H. Yi (2008), "Does Financial Development Cause Economic Growth? Implication for Policy in Korea", Journal of Policy Modelling, 30, 827-840. 
Yucel, F. (2009), “Causal relationships between financial development, trade openness and economic growth: the case of Turkey", Journal of Social Sciences, 5(1), 33-42.

\section{Appendix: Data}

The data used in this study are the quarterly data for the emerging markets between 1995 Q2 and 2013 Q2. The main source for the quarterly GDPs is the International Monetary Fund Financial Statistics (IFS). Data obtained from IFS are in current domestic prices. These data are converted into current dollars by using the exchange rates obtained from the same source. M2 money supplies are obtained from different sources like OECD, World Bank, and respective Central Banks. For the countries where M2 are quoted in domestic currencies, values are converted into current dollars by employing the same exchange rates used in converting GDP figures into dollars. For some countries, quarterly M2 values are estimated by using annual M2 Money Supply. The main sources for annual population data are FED Saint Louis, OECD and World Development Indicators. These annual figures are later converted into quarterly figures by interpolation technique. Finally, quarterly trade (Import and Export) values are obtained from IFS and FED Saint Louis database. For some countries values were annual, thus these values are transformed into quarterly values. Later, for those countries whose values are in domestic currencies are converted into current dollars. Logs of each data are used in estimations. 